\title{
Short-term Change in Forest Metrics at Grand Portage National Monument, Minnesota
}

\author{
SuZANNE SANDERS ${ }^{1,2}$ and JeSSica KirSChBaum ${ }^{1}$ \\ ${ }^{1}$ National Park Service, Great Lakes Inventory and Monitoring Network, 2800 Lake Shore Drive East, Ashland, Wisconsin \\ 54806 USA \\ ${ }^{2}$ Corresponding author: suzanne_sanders@nps.gov
}

Sanders, Suzanne, and Jessica Kirschbaum. 2017. Short-term change in forest metrics at Grand Portage National Monument, Minnesota. Canadian Field-Naturalist 131(2): 151-163. https://doi.org/10.22621/cfn.v131i2.1986

Forest health monitoring programs can provide routine feedback of key indices and periodic updates of ecosystem health. A forest monitoring program was initiated at Grand Portage National Monument in 2007 with plots resampled in 2014. Grand Portage National Monument is within the southern boreal forest and the suitable habitat for most of its common overstorey species is expected to shift northward and out of the park as climate change progresses. We assessed short-term change in forest health on 20 plots by specifically evaluating change in overstorey density and basal area, forest community composition, and White-tailed Deer (Odocoileus virginianus) browsing impacts on the herbaceous layer. Pooled across all overstorey species, both density and basal area increased between sampling events, but neither differed among habitats. For individual species of interest, responses were varied, although Balsam Fir (Abies balsamea) increased in both density and basal area over the seven years. The frequency of quadrats supporting at least one preferred browse species did not differ between sampling years although this was greater in upland plots $(81 \%)$ compared with wet mesic sites $(66 \%)$. The effect of sampling year on species' richness depended on habitat. In 2007, richness was higher in upland plots, although in 2014, richness was higher in wet mesic plots. Pooled across both sampling years, modified floristic quality index was greater in wet mesic plots. Our work demonstrates the increasing dominance of $A$. balsamea at Grand Portage National Monument and that notable differences in forest metrics can be observed over relatively short times.

Key Words: Boreal forest; browse ecological monitoring; forest change; Grand Portage National Monument; White-tailed Deer

\section{Introduction}

Forest health monitoring programs can provide information on the abundance and structure of individual species of interest (Duchesne et al. 2005; Fiedler and McKinney 2014), as well as the composition and integrity of plant communities as a whole (Steinman 2004; Auclair 2005). Provided they are designed properly, these monitoring programs can reveal relationships among biota such as herbivores and insect and fungal pests. Although parks and other natural areas are often designated as "unmanaged", park personnel may be tasked with promoting healthy forests that would otherwise occur in the absence of ongoing anthropogenic influences. Actions such as reductions in herbivore abundance (Tanentzap et al. 2011), prescribed fire (Mutch and Parsons 1998), thinning as a fire surrogate (Schwilk et al. 2009), seedbed preparation (York et al. 2012), snag creation (Brandeis et al. 2002), and invasive species removal (Flory and Clay 2009) are all examples of active management within parks. Ongoing forest health monitoring programs are needed by land managers to evaluate if management interventions may be necessary to promote ecological integrity (Lutes et al. 2006; Apostle Island National Lakeshore 2014).

Grand Portage National Monument (GPNM; 47. $9607^{\circ} \mathrm{N}, 89.6866^{\circ} \mathrm{W}$ ) is a 287 ha tract in northeastern Minnesota, near the boundary of northern mixed temperate forests and southern boreal forests. This park was established largely to commemorate the cultural legacy of the fur trade era and the native peoples of the region. It includes a $13.7 \mathrm{~km}$ foot path connecting Lake Superior with the Pigeon River, which serves as a portage trail, bypassing several major waterfalls on the lower reaches of the river. The park is surrounded by the Grand Portage Band of Lake Superior Chippewa reservation, a mosaic of forest and wetlands with large areas managed for timber.

Cultural resources at GPNM are tightly linked to natural resources, as both the fur traders and native peoples relied heavily on the forest. GPNM managers wish to promote species of cultural interest that are more resilient to impending climate-induced changes, thereby promoting both cultural and biological integrity. These species include Sugar Maple (Acer saccharum Marshall), Tamarack (Larix laricina (Du Roi) K. Koch), Red Pine (Pinus resinosa Aiton), Eastern White Pine (Pinus strobus L.), and both Trembling Aspen (Populus tremuloides Michaux) and Bigtooth Aspen (Populus grandidentata Michaux). These actions will aid in visitor interpretation of the fur trade, help maintain traditional uses of plants by the Ojibwa people, and restore the species composition of the forests to what was historically maintained via natural disturbance processes (National Park Service 2003).

Early settlement (prior to 1870) forest vegetation of GPNM varied along the trail. On the lower trail, nearer to Lake Superior, a matrix of $P$. tremuloides, Paper Birch 
(Betula papyrifera Marshall), Yellow Birch (Betula alleghaniensis Britton), and mixed conifers were dominant, while further inland, $P$. strobus and $P$. resinosa were most common on the landscape (Marschner 1974). Park managers especially wish to promote the pine component, namely $P$. strobus, due to its historical dominance. The current structure and composition are largely a result of human-induced fires during and after European settlement (ca. 1870-1910), followed by decades of fire suppression (White and Host 2003). Two early successional species, $B$. papyrifera and $P$. tremuloides, are now prominent as scattered mature individuals amid large numbers of standing dead trees and downed boles. Gaps are largely filled with young Balsam Fir (Abies balsamea (L.) Miller), along with dense Mountain Maple (Acer spicatum Lamarck) and Beaked Hazelnut (Corylus cornuta Marshall). In addition, selective foraging by both White-tailed Deer (Odocoileus virginianus) and Moose (Alces americanus) drive forest composition in the region (Pastor and Naiman 1992; White 2012). Deer browse heavily on P. strobus and Eastern White Cedar (Thuja occidentalis L.; White 2012) while A. balsamea is a preferred winter forage for Moose (De Jager and Pastor 2009). Both ungulates use a number of hardwood species during summer, limiting understorey development and initiating feedbacks with long-term consequences (Pastor and Naiman 1992; White 2012). Deer browse strongly impacts herbs by causing reductions in frequency (Balgooyen and Waller 1995) and loss of diversity (Rooney and Waller 2003).

The National Park Service (NPS) Great Lakes Inventory and Monitoring Network initiated a long-term monitoring program in 2007, at which time 20 permanent forest monitoring plots were established and sampled at GPNM. The overarching goal of this program is to conduct routine assessments of forest health by documenting the impacts of drivers (browse, climate change, etc.), stressors (pathogens, insect pests, precipitation, etc.), succession, and any other currently unforeseen impacts. These assessments will be used to guide forest management in the park. The initial 20 plots were resampled in 2014 and an additional three plots were established. Here we report on forest change from 2007-2014 to answer the following broad questions:

1) Have density or basal area of trees changed during the sampling interval? We posed this question first by including all species sampled, then by looking only at key species of interest, specifically: A. balsamea, $P$. tremuloides, B. papyrifera, . strobus, and Black Ash (Fraxinus nigra Marshall).

2) How has ungulate browsing impacted GPNM forests? We tested for evidence of browse impacts on the herbaceous layer. Browsing herbs often consumes the entire above-ground portion. Rather than bite marks, herbaceous browse generally results in fewer and small- er herbaceous species that are only indirectly evident over time. Therefore, we examined the collective frequency of eight preferred browse species, then also assessed height for two targeted taxa on which additional data were collected.

3) How has the plant community changed? We tested for differences in both species richness and the modified floristic quality index (mFQI; Rooney and Rogers 2002) between habitats and sampling events. The $\mathrm{mFQI}$ quantifies the degree of habitat faithfulness by species. Higher values indicate the presence of more specialist species, while lower values point to more generalists. We also used non-metric multidimensional scaling to see how plot locations shifted in ordination space during the seven-year sampling interval.

\section{Study Area}

GPNM is located within the Northern Superior Upland section (212L) of the Laurentian Mixed forest province (Ecoregion 212; Cleland et al. 1997). The mean July temperature high and low in Grand Portage during $1992-2014$ were $23.3^{\circ} \mathrm{C}$ and $11.4^{\circ} \mathrm{C}$, respectively. For January during that same period, the mean high and low were $-6.2^{\circ} \mathrm{C}$ and $-16.8^{\circ} \mathrm{C}$, respectively. Mean annual precipitation from 1992-2014 was $75.4 \mathrm{~cm}$ with $44 \%$ falling from May through August (www.climate analyzer.org).

GPNM is composed of a $13.7 \mathrm{~km}$ foot trail connecting Lake Superior with the Pigeon River; the park boundary provides a forested buffer of about $100 \mathrm{~m}$ on both sides of the trail for most of its length. At the Lake Superior terminus, a 28 ha tract of culturally maintained vegetation (mowed, garden, etc.) and historical buildings occupy the site. The Pigeon River trail terminus includes an expanded area of $44 \mathrm{ha}$, which is forested, with small openings for two primitive campsites. The Grand Portage Trail generally traverses high ground although several small streams cross it; moist pockets and forested wetlands are not uncommon within the buffer area on either side of the trail. A 2.1 ha American Beaver (Castor canadensis) pond is located along the trail, $9.4 \mathrm{~km}$ from the Lake Superior terminus.

Our sampling frame included all park lands except the Lake Superior tract, and the nearest $1.0 \mathrm{~km}$ of trail to the lake, because the park boundary here was only slightly wider than the trail itself.

\section{Methods}

\section{Data collection and treatment}

Sampling was conducted at GPNM during the summers of 2007 and 2014. Plot locations were chosen via a generalized random-tessellation stratified algorithm (Stevens and Olsen 2004), which ensured sites were randomly placed throughout the sampling frame, while also being spatially balanced. Specific details of the plot layout and field techniques are described by Sanders and Kirschbaum (2015), with an abbreviated version presented here. 
To answer our first question, we recorded the diameter at breast height (DBH), species, and live/dead status for all trees $\geq 2.5 \mathrm{~cm} \mathrm{DBH}$, within the $900 \mathrm{~m}^{2}$ tree sampling area of each plot (Figure 1).

Our second question addressed the impacts of ungulate browsing on herbaceous demography. These impacts are generally only indirectly observed over time as fewer and smaller individuals of preferred browse species (Webster et al. 2001; Kirschbaum and Anacker 2005), rather than as bite marks on individual plants. We used our personal knowledge to identify preferred browse species as those that are both relatively common in the region, and favoured by White-tailed Deer. While we are primarily interested in impacts by deer, browse from other herbivores was possible. Because browsing by Moose on herbaceous plants is generally limited to aquatic species, and that on terrestrial species typically occurs on woody shrubs and small tree branches (Aho and Jordan 1976), we assumed that impacts on herbs due to Moose were minimal. In addition, regional Moose densities have remained low for the decade preceding this work (DelGiudice 2015). Snowshoe Hare (Lepus americanus), however, do browse many of the same herbaceous species as White-tailed Deer (Belovsky 1984; Rouleau et al. 2002; Frerker et al. 2013); attributing browse impacts to either mammal is only possible using supporting, ancillary data. The preferred browse species we identified were White Baneberry (Actaea pachypoda Elliott), Red Baneberry ( $A$. rubra (Aiton) Willdenow), Wild Sarsaparilla (Aralia

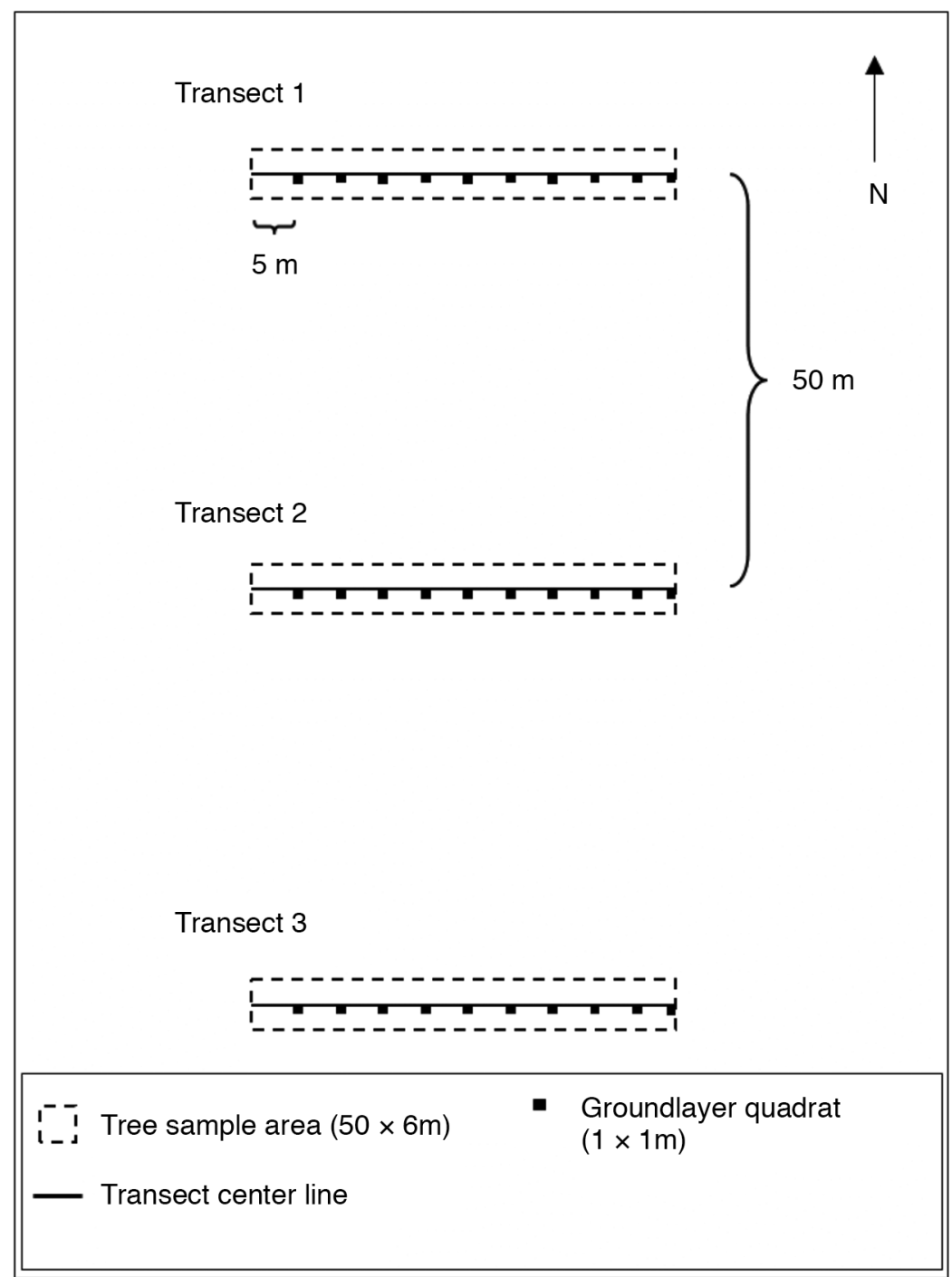

FIGURE 1. Plot layout, showing the three transects and 30 groundlayer quadrats. All data for herbaceous browse assessments were from the groundlayer quadrats. 
nudicaulis L.), Bluebead Lily (Clintonia borealis (Aiton) Rafinesque), False Solomon's Seal (Maianthemum racemosum (L.) Link), Clasping-leaved Twistedstalk (Streptopus amplexifolius (L.)), Rosy Twisted-stalk (S. lanceolatus var. roseus (Michx.) Reveal), and Nodding Trillium (Trillium cernuum L.). As part of our sampling protocols, we recorded all herbaceous species present in each of $30,1 \mathrm{~m}^{2}$ quadrats throughout the plot (Figure 1). We then used the groundlayer data to look at presence frequency from which we pooled all preferred browse species and determined the frequency of quadrats within plots where at least one of these species was present. We also assessed indirect impacts of browse by measuring the tallest of two target taxa (C. borealis and Streptopus spp.) within each quadrat where they were present. For each taxon we then calculated maximum height as the mean value of the tallest individuals in the plot.

We assessed plant community (the focus of our third question) by supplementing quadrat-level data with that obtained in a 30 min time-delimited search of each plot. Any species not previously noted were recorded.

We identified all plants to species while in the field, to the extent possible. When this was not possible, we collected specimens for later identification. In some instances, however, a lack of reproductive parts allowed identification only to genus or family. Examples include sedge (Carex sp.), shinleaf (Pyrola sp.), and Poaceae (grass family). For serviceberry (Amelanchier sp.), a genus that presented notable identification challenges, we assigned individual plants to one of three groups of species complexes, with Group 1 containing $A$. bartramiana; Group 2 containing A. arborea, A. laevis, and $A$. interior; and Group 3 containing an uncertain number of species (Smith 2008). All nomenclature follows the Integrated Taxonomic Information System System (ITIS 2014).

We grouped plots into similar types using cluster analysis. We constructed separate multivariate matrices based on abundance indices of both tree and groundlayer species within each plot. For the tree matrix, we calculated the importance value, determined by the mean of the relative density and relative basal area, for each species-plot combination (Dyer 2006; Elliott and Swank 2008). For the understorey (herb and shrub/ woody vine) matrix, the abundance for each speciesplot combination was determined by the proportion of groundlayer quadrats in which each species was located within that plot. For both trees and understorey, we limited inclusion in the cluster analysis to those taxa that were present in at least $8 \%$ ( 3 of 23) of the plots. For this analysis we used PC-ORD software (McCune and Grace 2002) and selected a Sørenson distance measure and a flexible beta linkage $(\beta=-0.25)$. Habitat type names were assigned based on the dominant trees in these groups. We used non-metric multidimensional scaling (NMS) to verify the legitimacy of these groups, using PC-ORD.
We identified coefficient of conservatism $(\mathrm{CoC})$ values for all species located during the sampling at GPNM. These values quantify the habitat faithfulness of species (Swink and Wilhelm 1994; Wilhelm and Masters 1995) and range from 0 (either non-native species or generalists with no faithfulness to any particular habitat) to 10 (conservative species found only within limited niches of certain non-degraded habitats). Because $\mathrm{CoC}$ values have not been assigned for terrestrial species in Minnesota, we used the values defined for Ontario (Oldham et al. 1995) for species present during our sampling. Two species, however, (Tea-leaved Willow [Salix planifolia Pursh] and Squashberry [Viburnum edule (Michaux) Rafinesque]) were not listed by Oldham et al. (1995), so we used CoC values assigned for wetland species in Minnesota (Milburn et al. 2007). We then used $\mathrm{CoC}$ values to calculate the modified floristic quality index (mFQI; Rooney and Rogers 2002; Sanders and Grochowski 2014) where $\mathrm{mFQI}$ is simply the mean of the $\mathrm{CoC}$ values for all species present within that plot.

\section{Forest change analyses}

To address our first question about forest change, we used two-way repeated measures analysis of variance (ANOVA) and tested whether density and basal area differed between sampling periods and between habitat types. We performed this analysis pooling all species, then individually for each key species of interest. For all two-way repeated measure ANOVA tests, two treatment effects (habitat and year) and their interaction (habitat $\times$ year), were considered fixed effects; the plot (habitat) term, and its interaction with year, were considered random effects. We also tested whether total sapling density differed between sampling periods or habitats, using the same model. All ANOVA tests were conducted using JMP (v. 7; SAS Institute Inc., Cary, North Carolina, USA). Lastly, we compared the diameter-distribution of trees in 2007 with that in 2014, by carrying out the Kolmogorov-Smirnov test using the R statistical software package (R Core Team 2012).

Our second question focused on ungulate browsing impacts. We tested for change between 2007 and 2014 using two indirect browse indices: the frequency of quadrats in each plot supporting at least one preferred browse species (i.e., frequency of presence), and the mean plot height of preselected target taxa. Again, we used two-way repeated measures ANOVA and tested whether these indices differed between years and habitats, as well as tested their interaction term.

Our third question asked whether plant communities differed between the sampling periods; we answered this using a suite of approaches. We first tested whether plot-level species richness and the mFQI differed between years or habitats, using two-way repeated measures ANOVA. For all 20 plots that were resampled, we then used non-metric multi-dimensional scaling (NMS) (McCune and Grace 2002) to view the similarity of plots relative to each another, in ordinal space. We 
applied vectors to denote the change in location of each plot between 2007 and 2014. Because we are assessing change in only a seven-year interval, we performed separate analyses for the overstorey (trees) and understorey (herbs and shrubs/woody vines). We felt the changes observed in the overstorey would largely be due to longer-term successional dynamics, while variation in the understorey would likely be in response to shorterterm impacts, including variation in browse pressure and precipitation. As with cluster analysis, the NMS was based on the importance value of trees for the overstorey analysis and the frequency of herbs and shrubs/ woody vines for the understorey analysis. We limited our dataset to taxa with at least three occurrences over the two sampling events. We also eliminated data on plants only identified to Carex sp. and Poaceae due to the broad ecological width occupied by these groups. We used an automated procedure beginning with 250 runs of real data and 250 runs to evaluate stability. These resulted in solutions with a final stress of 8.67 in the overstorey dataset and 10.85 for the understorey data.

\section{Results}

Among all 23 plots, we identified 20 tree species, 31 shrub and woody vine taxa, and 148 taxa of herbs. Plots were classified as one of two habitat types: upland spruce-fir-aspen (18 plots) and wet mesic mixed conifer/hardwood (five plots).

\section{Changes in density or basal area}

Our first question addressed whether density and/or basal area changed between sampling intervals. For all species collectively, both total density $\left(F_{1,22}=75.83\right.$, $P<0.0001)$ and total basal area $\left(F_{1,22} \stackrel{1,22}{=} 4.90, P=\right.$ $0.0400)$ increased significantly between the two sampling periods, although neither differed between habitats (Figure 2), nor depended on the sampling period $\times$ habitat interaction term.

We also tested if density and basal area are changing for key species of interest. Abies balsamea density and basal area depended on both year and habitat; both metrics were significantly greater in 2014 and in upland habitat (Table 1, Figure 3 ). Density of $P$. tremuloides

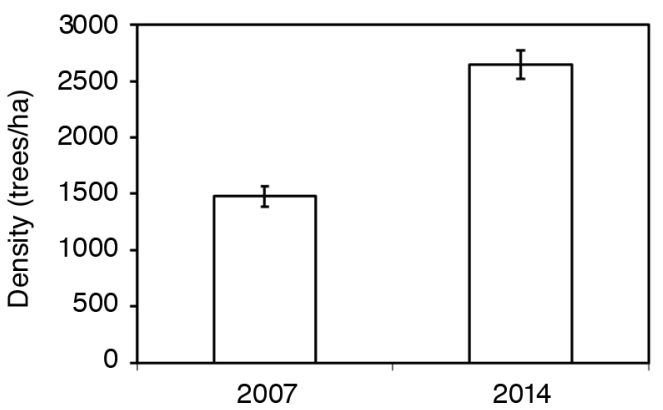

was significantly greater in $2014(525 \pm 35.5$ [SE] trees/ha versus $232 \pm 89.5$ [SE] trees/ha in 2007), but did not differ significantly between habitats; $P$. tremuloides basal area did not differ significantly by habitat or year (Table 1). For B. papyrifera, neither metric differed significantly by habitat or year. Likewise, neither metric for $P$. strobus differed significantly on the year sampled; we could not test for differences between habitats due to inadequate sample size. Fraxinus nigra density did not differ significantly between years or habitats, although basal area tended toward being greater in $2007(0.731 \pm 0.309$ [SE] m²/ha versus 0.603 $\pm 0.242[\mathrm{SE}] \mathrm{m}^{2} /$ ha in 2014; Table 1 ).

Across both habitat types, the density-diameter class distributions differed significantly between the sampling periods (Kolmogorov-Smirnov test; $P<0.0001$; Figure 4).

\section{Impacts of deer browsing}

A test of the indirect impact of deer browsing on herb abundance showed that the frequency of quadrats supporting at least one preferred browse species did not differ between years $\left(F_{1,22}=0.31, P=0.5846\right)$ although it tended to depend on habitat $\left(F_{1,22}=4.06, P=\right.$ 0.0572 ). Across both years, $81 \%$ of quadrats in upland plots supported at least one preferred browse species, while only $66 \%$ of wet mesic sites did so. For C. borealis, mean height within plots was significantly greater among sampling years $\left(F_{1,15}=5.17, P=0.0344\right)$ with a tendency for mean height to also differ between habitats $\left(F_{1,15}=3.65, P=0.0698\right.$; Figure 5$)$. Across both habitats, mean plot height of $C$. borealis was $12.4 \pm$ 0.592 [SE] cm in 2007 and $13.2 \pm 0.527$ [SE] $\mathrm{cm}$ in 2014; across both years, mean height was $12.4 \pm 0.439$ $[\mathrm{SE}] \mathrm{cm}$ in upland habitat and $14.4 \pm 0.690[\mathrm{SE}]$ in wet mesic sites. Streptopus sp. height did not differ significantly between habitats $\left(F_{1,18}=0.76, P=0.3937\right)$ or sampling years $\left(F_{1,18}=2.69, P=0.1183\right)$.

\section{Plant community composition}

The effect of sampling year on mean plot species richness depended on habitat (i.e., significant interaction term, $F_{1,1}=12.85, P=0.0020$; Figure 6). In 2007, richness was higher in upland plots $(61.2 \pm 1.53[\mathrm{SE}]$

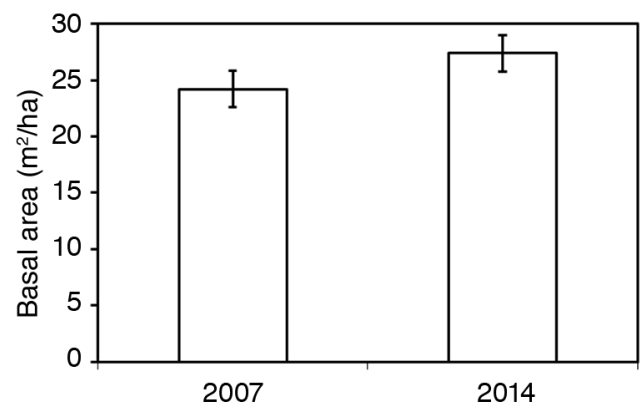

FIGURE 2. Density and basal area for live trees of all species in both 2007 and 2014. Results are pooled across both habitat types. Both indices were greater in 2014. Error bars reflect the standard error. 
TABLE 1. ANOVA $P$ values for density, basal area, and their interaction, of five key species of interest.

\begin{tabular}{llccc}
\hline \hline Species & Metric & Habitat & Year & Habitat $\times$ Year \\
\hline Balsam Fir (Abies balsamea) & density & 0.0161 & $<0.0001$ & 0.7287 \\
Trembling Aspen (Populus tremuloides) & basal area & 0.0002 & 0.0034 & 0.1159 \\
& density & 0.0710 & 0.0002 & 0.1042 \\
Yellow Birch (Betula papyrifera) & basal area & 0.9996 & 0.3461 & 0.1556 \\
& density & 0.6964 & 0.2028 & 0.8989 \\
White Pine (Pinus strobus)* & basal area & 0.5271 & 0.6437 & 0.6258 \\
Black Ash (Fraxinus nigra) & density & & 0.2053 & 0.8342 \\
& basal area & & 0.1951 & 0.8931 \\
\hline \hline
\end{tabular}

"Inadequate sample size precluded tests of habitat and interactive effects on Pinus strobus.
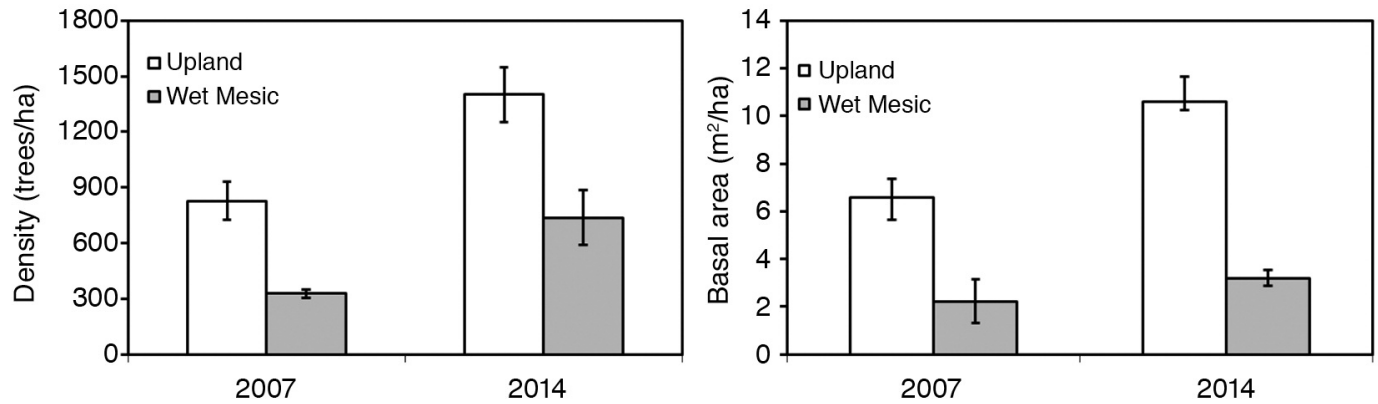

FiguRE 3. Density and basal area of Balsam Fir (Abies balsamea) in both habitats and years. Both metrics were greater in 2014 and in upland habitat. Error bars reflect the standard error.

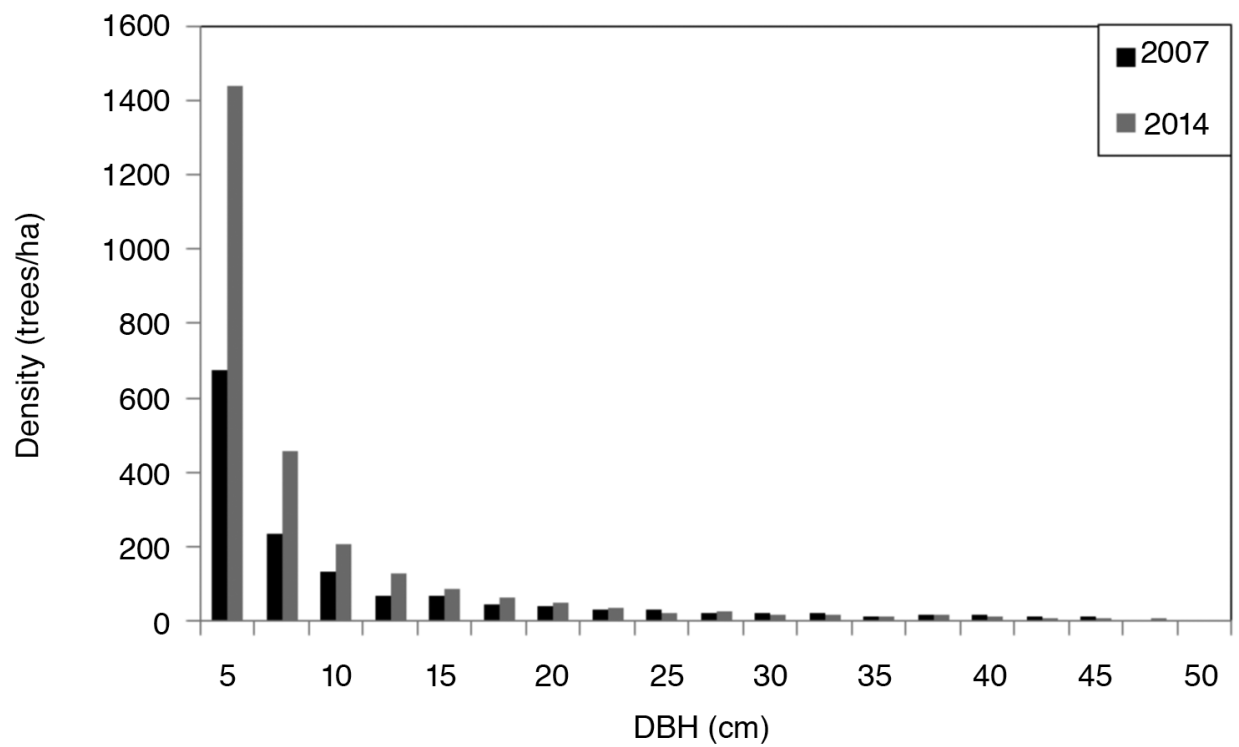

FIGURE 4. Density-diameter at breast height (DBH) distributions for trees differed between the two sampling periods. Results are pooled across both habitat types and included all species. 


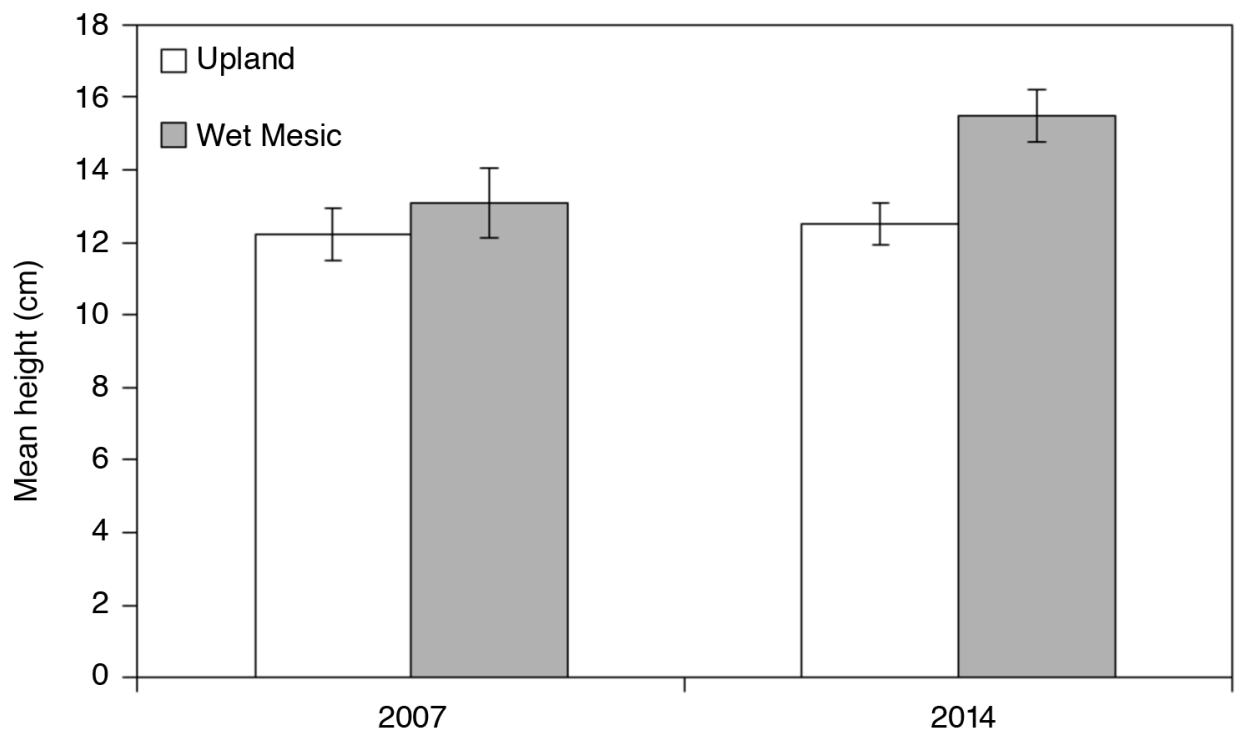

FIGURE 5. Height of Bluebead Lily (Clintonia borealis), a target preferred browse species, in both habitats and sampling periods. Height was greater in 2014 and tended toward being greater in wet mesic habitats. Error bars reflect the standard error.

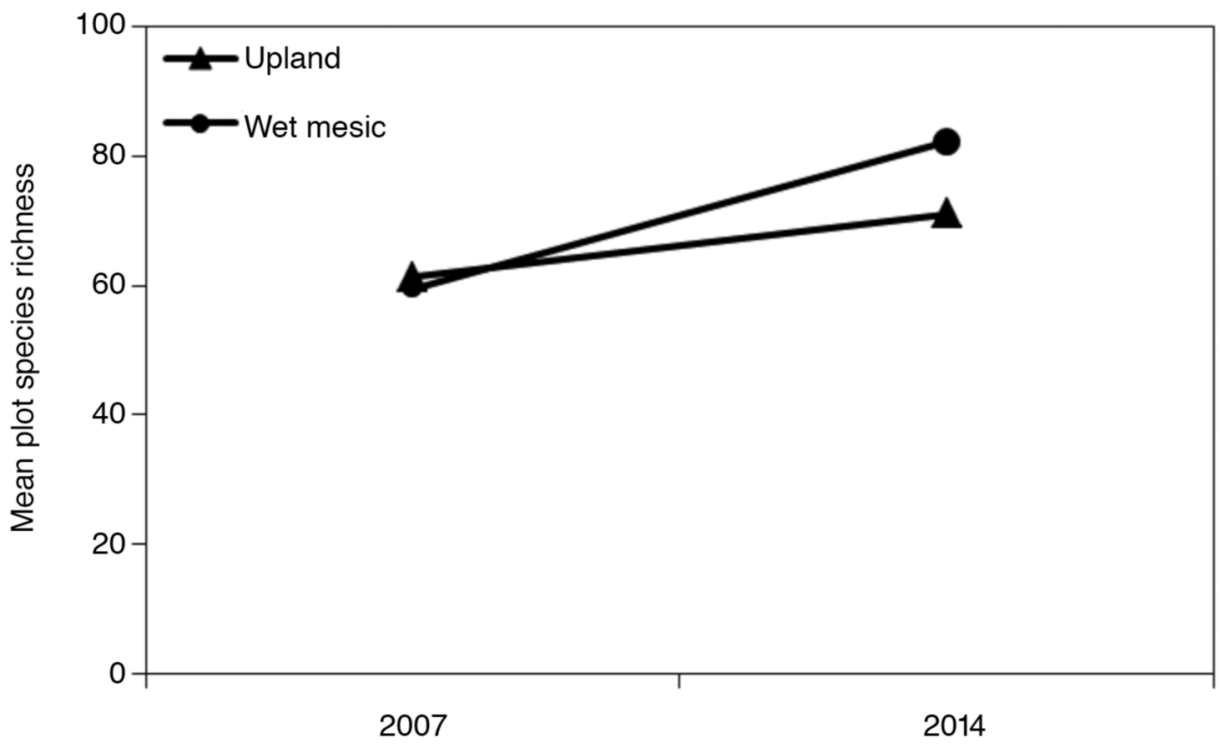

FIGURE 6. Mean plot species richness in both habitats and sampling periods.

versus $59.5 \pm 2.02[\mathrm{SE}]$ ), although in 2014 , richness was higher in wet mesic plots $(82.2 \pm 3.5[\mathrm{SE}]$ versus $71 \pm 2.3[\mathrm{SE}])$.

The mFQI did not differ significantly between years $\left(F_{1,22}=0.10, P=0.7575\right)$ although there was a trend toward significant difference between habitats $\left(F_{1,22}=4.13, P=0.0540\right)$. Pooled across both sampling years, $\mathrm{mFQI}$ was $4.88 \pm 0.044$ [SE] in upland plots and $5.08 \pm 0.086[\mathrm{SE}]$ in wet mesic plots.

The NMS ordination results on overstorey data (Figure 7) support our other findings of marked increases in both A. balsamea and P. tremuloides. Vectors corresponding with increasing values of both Axes 1 and 2 (i.e., pointing toward the upper right) represent 


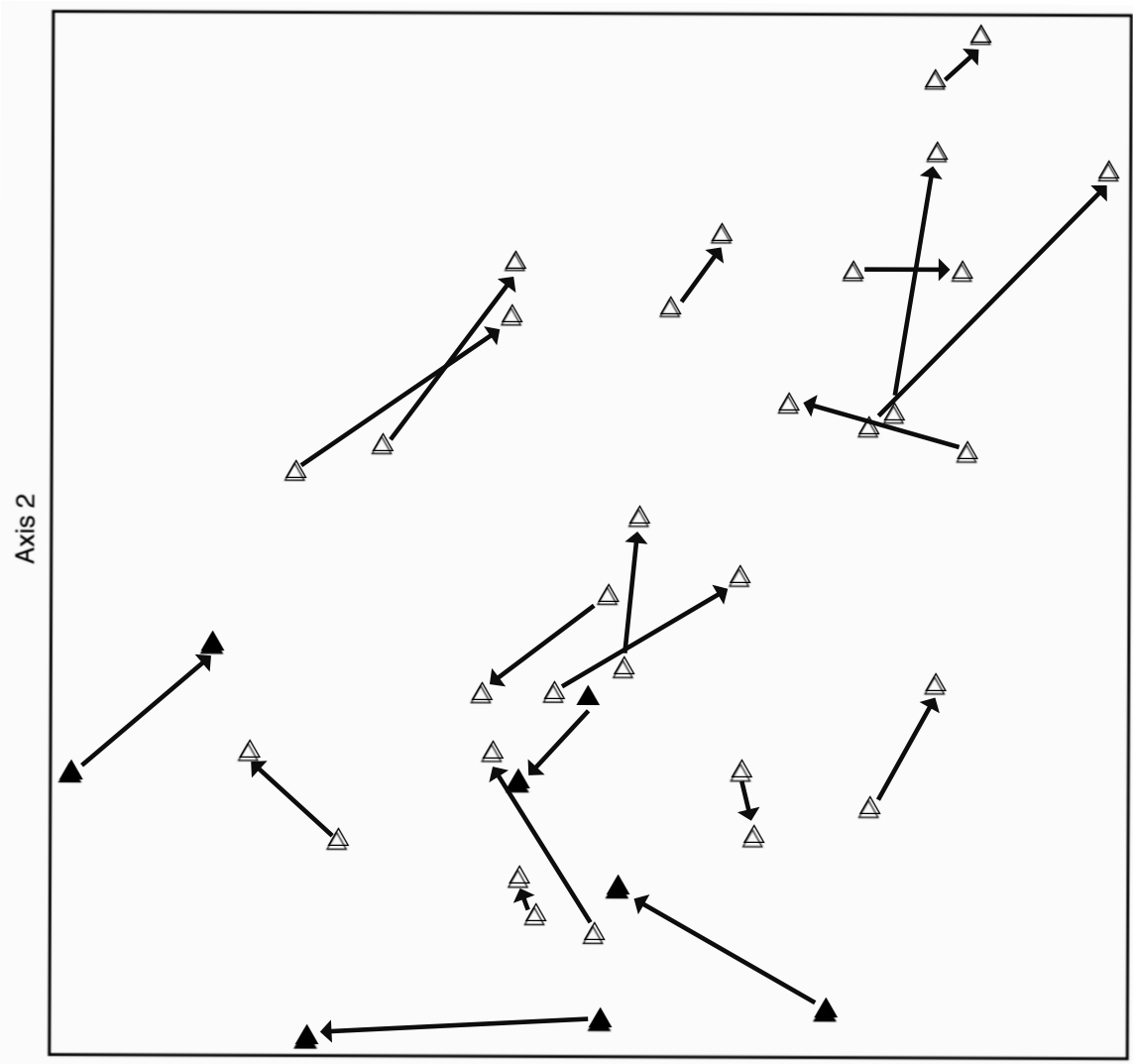

Axis 1

FIGURE 7. Nonmetric Multidimensional Scaling ordination of overstorey data with vectors drawn from the 2007 location to the 2014 location for each plot. Open triangles are plots in in upland habitat; solid triangles are plots in wet mesic habitat.

plots with large increases in density of A. balsamea. Those vectors pointing toward the upper left, representing decreasing values of Axis 1 and increasing values of Axis 2, correspond with plots with large density increases in both $A$. balsamea and $P$. tremuloides. The correlation coefficient $(r)$ for each overstorey species on Axes 1 and 2 (Table 2 ) reflects this; low Axis 2 values are also observed for $F$. nigra and A. spicatum, which experienced substantial ingrowth in a small handful of plots.

The NMS Ordination on understorey abundance showed a strong directional pattern, with all plots increasing along Axis 2 (Figure 8). While this signal appeared particularly strong for a small number of herbs

TABLE 2. Nonmetric Multidimensional Scaling axis correlations for overstorey species present in at least three plots.

\begin{tabular}{lcr}
\hline \hline Species & Axis 1 & Axis 2 \\
\hline White Pine (Pinus strobus) & -0.638 & 0.007 \\
Trembling Aspen (Populus tremuloides) & -0.409 & -0.429 \\
Balsam Poplar (Populus balsamifera) & -0.363 & -0.288 \\
White Spruce (Picea glauca) & -0.323 & 0.116 \\
Black Ash (Fraxinus nigra) & -0.310 & -0.520 \\
White Cedar (Thuja occidentalis) & -0.310 & -0.340 \\
Bebb Willow (Salix bebbiana) & -0.191 & 0.088 \\
Mountain Maple (Acer spicatum) & -0.116 & -0.603 \\
Choke Cherry (Prunus virginiana) & -0.014 & -0.012 \\
Mountain Ash (Sorbus decora) & -0.013 & 0.157 \\
Sugar Maple (Acer saccharum) & 0.145 & 0.191 \\
Black Ash (Picea mariana) & 0.177 & -0.059 \\
Paper Birch (Betula papyrifera) & 0.267 & -0.421 \\
Balsam Fir (Abies balsamea) & 0.756 & 0.913 \\
\hline \hline
\end{tabular}




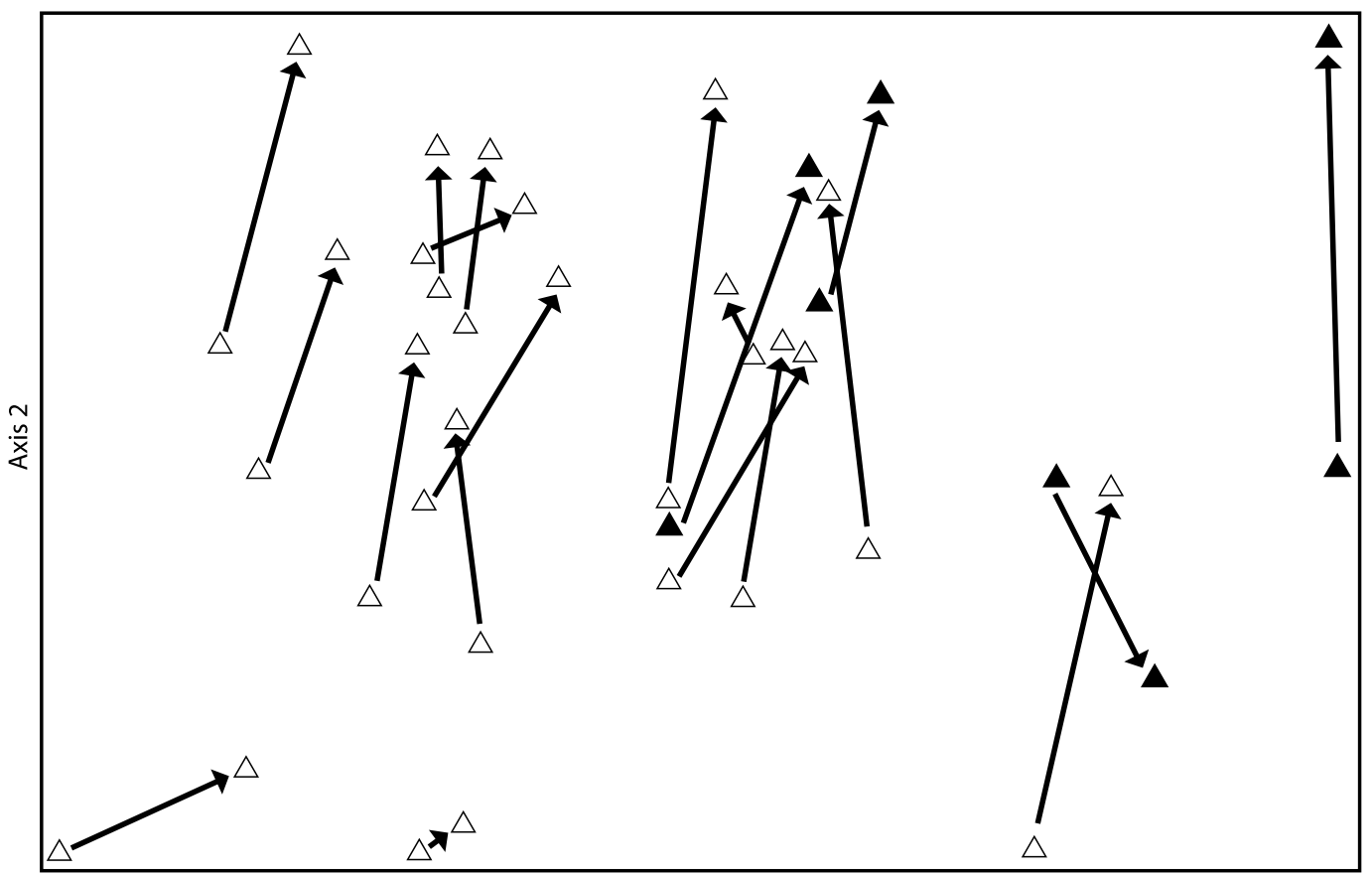

Axis 1

FIGURE 8. Nonmetric Multidimensional Scaling ordination of herbaceous and shrub data with vectors drawn from the 2007 location to the 2014 location for each plot. Open triangles are plots in upland habitat; solid triangles are plots in wet mesic habitat.

(including Wood Anemone [Anemone quinquefolia L.] and Bunchberry [Cornus canadensis L.]) the directional pattern was also present in those plots where decreases in these species were observed.

\section{Discussion}

Our results of overstorey change observed over the seven-year sampling interval mirror those of other studies throughout the region (Friedman and Reich 2005; Frelich and Reich 2009a). Early successional hardwoods, which were established at the time of stand initiation, have aged and shade tolerant species dominated by $A$. balsamea became established. As most stands are now nearing or beyond 100 years old, those early successional species, dominated by $P$. tremuloides, are being killed by a mix of factors, including windthrow, root disease, Forest Tent Caterpillar (Malacosoma disstria), and drought. The gap-phase forest is now a mosaic of young $A$. balsamea, with A. spicatum and clones of $P$. tremuloides colonizing the gaps. Our observation of dual high density of both A. balsamea and P. tremuloides is somewhat unusual because they generally occur on opposite ends of the successional spectrum. As stands aged, $A$. balsamea gradually became established under the $P$. tremuloides canopy; subsequent losses of individuals from the oldest $P$. tremuloides cohort, composed of trees typically $>30 \mathrm{~cm}$ diameter, most likely promoted root suckering and adventitious shoot growth of clones, in response to the loss of apical dominance (Wan et al. 2006). High density of both of these species is not commonly observed in managed forests because harvest of early successional species often occurs before later-successional species become well established.

Pinus strobus, while historically common, now exists at low densities across the landscape; an arrangement that limits the spatial extent of seed rain which, in turn, hinders regeneration. In the absence of fire, A. balsamea dominance will likely increase as other species adapted to fire become less prominent. One possible check on A. balsamea dominance, however, is a future outbreak of Spruce Budworm (Choristoneura fumiferana), a native species that attacks spruce, fir, and several other genera of conifer. An infestation in spruce-fir stands in Minnesota in the 1970s resulted in a reduction in stand basal area from $79 \%$ to $31 \%$ of the total (Batzer and Popp 1985).

Precipitation differences between the two sampling years may explain the patterns observed in understorey plant communities. Precipitation during the mean growing season (May-August) from 1992 to 2014 was $33.5 \mathrm{~cm}$ (Climate Analyzer 2015). The 2007 sampling occurred during a relatively dry period with $24.5 \mathrm{~cm}$ and $17.4 \mathrm{~cm}$ of precipitation during the 2006 and 2007 growing seasons, respectively. The climate was wetter during the later sampling when mean growing season 
precipitation totalled $39.0 \mathrm{~cm}$ in 2013 and $41.3 \mathrm{~cm}$ in 2014. In 2014, wet mesic sites supported 11.2 more species than upland sites while in 2007, a dry year, wet mesic sites support 1.7 fewer species. It is possible that species adapted to more moist areas may have been reduced in abundance by more competitive generalists. Specialist species, by definition, will have higher coefficients of conservatism. Greater mFQI in wet mesic sites, relative to upland sites is therefore, not surprising.

The lower frequency of preferred browse species in wet mesic plots relative to upland sites suggests these areas with wet pockets constitute poorer habitat for our target species. Throughout the wet mesic plots were patches of Bluejoint (Calamagrostis canadensis (Michx.) P. Beauv.), Spotted Touch-me-not (Impatiens capensis Meerburgh), and Common Lady Fern (Athyrium filix-femina (L.) Roth). While we observed only a minimal amount of standing water at these sites during our sampling, these species suggest the presence of water was greater in the spring, likely limiting the areas where target species occur. Our finding of a trend that $C$. borealis was taller in wet mesic sites could suggest that browse pressure may be reduced here, although we did not find this with our other target species, $S$. lanceolatus var. roseus. In future sampling, we will measure height of three target species allowing for a fuller assessment of browse impacts on herb height.

The findings presented here for browse should not be interpreted too robustly. In general, neither deer, nor hare browsing pressure is currently high in the area. While White-tailed Deer abundance has increased over the previous decade on the Grand Portage Reservation, the density is still relatively low. Winter helicopter surveys counted 56 White-tailed Deer in 2007 and 205 White-tailed Deer in 2014 over the $193 \mathrm{~km}^{2}$ reservation land base (E. Isaac, personal communication). Conservatively, these would correspond to spring densities of 0.29 and 1.08 deer $/ \mathrm{km}^{2}$, respectively. These values are low compared with both current densities throughout the Upper Midwest Region (Rooney and Waller 2003) and with pre-European settlement estimates of 2-4 deer $/ \mathrm{km}^{2}$ in deciduous and mixed deciduous-conifer forests of the region (Alverson et al. 1988). As such, the current White-tailed Deer density is not likely to suppress regeneration of these herbs. Deer densities are low due to deep winter snow accumulation in northeast Minnesota (Nelson 1995). As climate change progresses, and winter snow loads decrease, our data from 2007 and 2014 can be used to assess any changes in browsing impacts to vegetation.

Snowshoe Hare impacts are less clear. Hare densities peak then crash on a 10 -year cycle driven largely by the interacting effects of predation and food availability (Krebs et al. 2001). While the herbaceous dietary preferences of hare are similar to those of deer (Belovsky 1984; Rouleau et al. 2002; Frerker et al. 2013), Wolff (1978) showed that herbs composed about $50 \%$ of the diet of hare in central Alaska only during the month of May, while in April and in the summer, herbs represented only about $10 \%$ of the hare diet. In northern Minnesota, Snowshoe Hare density peaked in 2011 with nearly 5 hares/100 km of survey line (Erb 2014); hare densities at the time of both of our sampling events (2007 and 2014) were at the cycle mid-point, half way between the high and low. We are unaware of any work quantifying the relationship between hare abundance and impacts to the herbaceous layer.

The differences observed in this study between sampling events for the overstorey, and especially for the herbaceous layer were somewhat surprising, given the short time interval between them. Obviously, the different time between sampling dates for the 2007 (8 June - 19 July) and 2014 (22 June - 19 August) event could contribute to this, although we feel would only be a minor factor, if any at all. The latest-emerging species at GPNM are the July-flowering asters that were observed (pre-flowering) during our training period in early June. Conversely, the taxa which typically exhibit the earliest sign of senescence in the park are Starflower (Trientalis borealis Rafinesque) and various fern species. Although chlorosis was evident during the final week of sampling in 2014, they were still distinctive, and were easily identified throughout the park, at least through the final sampling day. The degree to which our observed differences reflect true directional change versus simply a response to stochastic yearto-year variation is unclear. Dynamics such as deer abundance (and hence, browsing), precipitation, and severe wind can vary highly between years leading to large differences between closely-timed sampling events. Analyses of vegetation change are often opportunistic resampling events on the order of 50 years (Jones et al. 1994; Johnson et al. 2014), rather than shorter-term studies with planned revisit schedules and pre-identified questions (for an exception, see Taverna et al. [2005]). Interpretation of results of these longterm studies may warrant a brief discussion on the drivers and stressors that may be acting on the systems near the time of both the initial and follow-up sampling events. For this current project, we are scheduled to sample a third time in 2024 with repeated sampling approximately every $9-10$ years. This should allow us to parse out long-term trends versus shorter term variability.

\section{Management and Climate Change}

While our work follows convention by using traditional statistical approaches to test for change, we caution against a strict interpretation. Forests may be in the early stages of displaying climate change-induced shifts and managers need to recognize these changes, whether statistically significant or not. GPNM is situated at the boundary between the boreal forest to the north and Laurentian mixed forest to the south. As such, many boreal species present in the park are near their southern range limits; favourable habitat conditions for their reproduction and growth are predicted to migrate north- 
ward and out of the region (Frelich and Reich 2009a). In their stead, the growing conditions are expected to become more favourable for oaks (Quercus spp.) and pines (Pinus spp.; Frelich and Reich 2009b). It is currently unclear, however, whether the migration rates of these groups can keep pace with the migration rate of their climate envelope (Frelich and Reich 2009a).

Climate change resilience strategies focus on promoting the growth of species expected to remain in the area, while minimizing the spread of newly arriving invasive species. Park managers have implemented a project to promote $P$. strobus regeneration within the park by outplanting for seed rain restoration, releasing advance regeneration, and also manually controlling $A$. balsamea. This project encourages current regeneration of $P$. strobus so that seed sources may be available for future regeneration once $A$. balsamea begins to die out. Managers may also wish to promote the growth of other species expected to remain in the area, including $B$. papyrifera and T. occidentalis. While the former species is often early successional, the latter can be slow-growing and long-lived (Fowells 1965). Germination and seedling growth of $T$. occidentalis preferentially occurs under a Thuja canopy (Cornett et al. 1997) and on coarse wood substrates (Cornett et al. 2001); because of this feedback, maintaining and promoting existing populations and coarse woody structures should be a priority. Indeed, long-term goals of the park include promoting conifer cover in riparian corridors, in conjunction with $T$. occidentalis seed rain. This may create a feedback loop by promoting greater moisture and shading, and hence providing refugia for southern boreal conifers.

While climate change is an important concern to the park, a more immediate concern to park managers is the arrival of Emerald Ash Borer (Agrilus planipennis). As of spring 2015, this exotic insect is now established in Duluth, Minnesota, approximately $233 \mathrm{~km}$ to the southwest of GPNM. Fraxinus nigra was located in 16 of the 23 plots; most of these plots were located in the half of the trail closer to Pigeon River. None were in the nearest $3 \mathrm{~km}$ to Lake Superior. In areas where we observed $F$. nigra, we also commonly observed populations of Speckled Alder (Alnus incana subsp. rugosa (Du Roi) R.T. Clausen) with smaller inclusions of Green Alder (Alnus viridis subsp. crispa (Aiton) Turrill). It is likely that populations of these species of alder will expand and fill niches left vacant by ash trees once Emerald Ash Borer arrives and ash trees begin to succumb to it.

\section{Broader Relevance}

While our work is limited to GMNP, its relevance extends throughout northern Minnesota. This region is heavily forested, and includes a state forest, numerous state parks, and the Superior National Forest. The latter encompasses the 441000 ha Boundary Waters Canoe Area Wilderness and is adjacent to the 460000 ha Quetico Provincial Park in Ontario. Both of these areas are largely unmanaged and are subject to the same pressures as GPNM. Our results demonstrate what can happen in the absence of fire; they can be used by managers of these other areas as one part of a decision tool, where prescribed fire is a valid option.

Perhaps the most relevant aspect of our work may also be in advancing efforts to assess browsing by deer, particularly in the summer and/or on herbaceous species. While the deer population is not currently high at GPNM, high deer densities elsewhere in the northern Great Lakes Region are the norm (Rooney and Waller 2003). Deer browsing is driving regional species loss and homogenization in forests ( $\mathrm{Li}$ and Waller 2015), and there is great interest in developing methods to assess its impacts. There is also growing recognition that assessing herbaceous browse by bite marks is of limited value because deer frequently consume entire plants. While our specific methods may not necessarily fit the monitoring protocols of others, our work shows how monitoring for change over time in the frequencies of understorey species can be used to monitor impacts by deer browsing.

Much of northern Minnesota is heavily forested. With Lake Superior to the east, and grasslands to the west, this region may emerge as a corridor through which species migrate northward and northeastward as temperatures warm and associated climate change continues. Because of the key biogeographic role that the forests of northern Minnesota may play in the future, we need to learn about current, shorter-term vegetation dynamics. Regeneration successes and failures, browsing impacts, and species' competitive abilities will likely all weigh heavily on forest management decisions in the region over the next 50 years. Our work here may serve as one resource that managers draw on as they face these decisions.

\section{Acknowledgements}

Major funding was provided by the National Park Service, Inventory and Monitoring Division. Additional funding was provided by Anthony D'Amato and the University of Minnesota. We are grateful for the vegetation monitoring field crew of Christine Groebner and Kaylee Nelsen. Without their assistance, this project would not have been possible. We are also indebted to Brandon Seitz, Bill Clayton, and many others on staff at the Grand Portage National Monument for planning, logistical, and administrative assistance. We wish to thank Edmund Isaac of the Grand Portage Band of the Minnesota Chippewa for providing deer density estimates (14 October 2015). Finally, we greatly appreciate Anthony D'Amato, Brandon Seitz, Mark White, Rolf Peterson, and two anonymous reviewers for providing reviews of earlier drafts of this manuscript.

\section{Literature Cited}

Aho, R. W., and P. A. Jordan. 1976. Production of aquatic macrophytes and its utilization by moose on Isle Royale National Park. Pages 341-348 in Proceedings of the First 
Conference on Scientific Research in the National Parks. U.S. Department of the Interior, New Orleans, Louisiana, USA.

Alverson, W. S., D. M. Waller, and S. L. Solheim. 1988. Forests too deer: edge effects in northern Wisconsin. Conservation Biology 2: 348-358. https://doi.org/10.1111/j. 1523-1739.1988.tb00199.x

Apostle Islands National Lakeshore. 2014. Harvestable species plan: Apostle Islands National Lakeshore. Bayfield, Wisconsin, USA. Accessed 28 June 2017. https://www.nps .gov/apis/learn/management/upload/CURRENT-Harvest able-Species-Plan-w-out-EA-4-14.pdf.

Auclair, A. N. D. 2005. Patterns and general characteristics of severe forest dieback from 1950-1995 in the northeastern United States. Canadian Journal of Forest Research 35: 1342-1355. https://doi.org/10.1139/x05-066

Balgooyen, C. P., and D. M. Waller. 1995. The use of Clintonia borealis and other indicators to gauge impacts of white-tailed deer on plant communities in northern Wisconsin, USA. Natural Areas Journal 15: 308-318.

Batzer, H. O., and M. P. Popp. 1985. Forest succession following a spruce budworm outbreak in Minnesota. The Forestry Chronicle 61: 75-80. https://doi.org/10.5558/tfc 61075-2

Belovsky, G. E. 1984. Snowshoe hare optimal foraging and its implications for population dynamics. Theoretical Population Biology 25: 235-264. https://doi.org/10.1016/00405809(84)90009-1

Brandeis, T. J., M. Newton, G. M. Filip, and E. C. Cole. 2002. Cavity-nester habitat development in artificially made Douglas-fir snags. Journal of Wildlife Management 66: 625-633. https://doi.org/10.2307/3803129

Cleland, D. T., P. E. Avers, W. H. McNab, M. E. Jensen, R. G. Bailey, T. King, and W. E. Russell. 1997. National hierarchical framework of ecological units. Pages 181200 in Ecosystem Management Applications for Sustainable Forest and Wildlife Resources. Edited by M. S. Boyce and A. Haney. Yale University Press, New Haven, Connecticut, USA.

Climate Analyzer. 2015. Climate data online. Walking Shadow Ecology, Gardner, Montana, USA. Accessed 29 July 2015. http://www.climateanalyzer.org/glkn/grand portage.

Cornett, M. W., P. B. Reich, and K. J. Puettmann. 1997. Canopy feedbacks and microtopography regulate conifer seedling distribution in two Minnesota conifer-deciduous forests. Écoscience 4: 353-364. http://dx.doi.org/10.1080/ 11956860.1997.11682414

Cornett, M. W., K. J. Puettmann, L. E. Frelich, and P. B. Reich. 2001. Comparing the importance of seedbed and canopy type in the restoration of upland Thuja occidentalis forests of northeastern Minnesota. Restoration Ecology 9: 386-396. http://dx.doi.org/10.1046/j.1526-100X.2001.94 008.x

De Jager, N. R., and J. Pastor. 2009. Declines in moose population density at Isle Royale National Park, MI, USA and accompanied changes in landscape patterns. Landscape Ecology 24: 1389-1403. http://dx.doi.org/10.1007/s10980009-9390-4

DelGiudice, G. D. 2015. 2015 Aerial moose survey. Report to the Minnesota Department of Natural Resources. Minnesota Department of Natural Resources, St. Paul, Minnesota, USA.

Duchesne, L., R. Ouimet, J.-D. Moore, and R. Paquin. 2005. Changes in structure and composition of maple-beech stands following sugar maple decline in Québec, Canada.
Forest Ecology and Management 208: 223-236. https:// doi.org/10.1016/j.foreco.2004.12.003

Dyer, J. M. 2006. Revisiting the deciduous forests of eastern North America. BioScience 56: 341-352. https://doi.org /10.1641/0006-3568(2006)56[341:RTDFOE]2.0.CO;2

Elliott, K. J., and W. T. Swank. 2008. Long-term changes in forest composition and diversity following early logging (1919-1923) and the decline of American chestnut (Castanea dentata). Plant Ecology 197: 155-172. https://doi .org/10.1007/s11258-007-9352-3

Erb, J. 2014. Furbearer winter track survey summary, 2014. Report from the Forest Wildlife Populations and Research Group, Minnesota Department of Natural Resources, Grand Rapids, Minnesota, USA.

Fiedler, C. E., and S. T. McKinney. 2014. Forest structure, health, and mortality in two Rocky Mountain whitebark pine ecosystems: implications for restoration. Natural Areas Journal 34: 290-299. https://doi.org/10.3375/043.034.0305

Flory, S. L., and K. Clay. 2009. Invasive plant removal method determines native plant community responses. Journal of Applied Ecology 46: 434-442. https://doi.org/10.1111/j .1365-2664.2009.01610.x

Fowells, H. A. 1965. Silvics of forest trees of the United States. U.S. Department of Agriculture, Agriculture Handbook 271. Washington, DC, USA.

Frelich, L. E., and P. B. Reich. 2009a. Wilderness conservation in an era of global warming and invasive species: a case study from Minnesota's Boundary Waters Canoe Area Wilderness. Natural Areas Journal 29: 385-393. https://doi .org/10.3375/043.029.0405

Frelich, L. E., and P. B. Reich. 2009b. Will environmental changes reinforce the impact of global warming on the prairie-forest border of central North America? Frontiers in Ecology and the Environment 8: 371-378. https://doi .org/10.1890/080191

Frerker, K., G. Sonnier, and D. M. Waller. 2013. Browsing rates and ratios provide reliable indices of ungulate impacts on forest plant communities. Forest Ecology and Management 291: 55-64. https://doi.org/10.1016/j.foreco .2012 .11 .041

Friedman, S. K., and P. B. Reich. 2005. Regional legacies of logging: departure from presettlement forest conditions in northern Minnesota. Ecological Applications 15: 726-744 https://doi.org/10.1890/04-0748

ITIS (Integrated Taxonomic Information System). 2014 ITIS online database. Accessed 2 February 2015. https:// www.itis.gov.

Johnson, S. E., E. L. Mudrak, and D. M. Waller. 2014. Local increases in diversity accompany community homogenization in floodplain forest understories. Journal of Vegetation Science 25: 885-896. https://doi.org/10.1111/ jvs. 12147

Jones, R., R. R. Sharitz, P. M. Dixon, D. S. Segal, and R. L. Schneider. 1994. Woody plant regeneration in four floodplain forests. Ecological Monographs 64: 345-367. https:// doi.org/10.2307/2937166

Kirschbaum, C. D., and B. L. Anacker. 2005. The utility of Trillium and Maianthemum as phyto-indicators of deer impact in northwestern Pennsylvania, USA. Forest Ecology and Management 217: 54-66. https://doi.org/10.1016/ j.foreco.2005.05.001

Krebs, C. J., R. Boonstra, S. Boutin, and A. R. E. Sinclair. 2001. What drives the 10 -year cycle of snowshoe hares? BioScience 35: 25-35. https://doi.org/10.1641/0006-3568 (2001)051[0025:WDTYCO]2.0.CO;2 
Li, D., and D. M. Waller. 2015. Drivers of observed biotic homogenization in pine barrens of central Wisconsin. Ecology 96: 1030-1041. https://doi.org/10.1890/14-0893.1

Lutes, D. C., R. E. Keane, J. F. Caratti, C. H. Key, N. C. Benson, S. Sutherland, and L. J. Gangi. 2006. FIREMON: fire effects monitoring and inventory system. General Technical Report RMRS-GTR-164-CD. U.S. Department of Agriculture, Forest Service, Rocky Mountain Research Station, Fort Collins, Colorado, USA.

Marschner, F. J. 1974. The original vegetation of Minnesota, a map compiled in 1930 by F. J. Marschner under the direction of M. L. Heinselman of the US Forest Service. St. Paul, Minnesota, USA.

McCune, B., and J. B. Grace. 2002. Analysis of Ecological Communities. MjM software, P.O. Box 129, Gleneden Beach, Oregon, USA.

Milburn, S. A., M. Bourdaghs, and J. J. Husveth. 2007. Floristic Quality Assessment for Minnesota Wetlands. Minnesota Pollution Control Agency, St. Paul, Minnesota, USA.

Mutch, L. S., and D. J. Parsons. 1998. Mixed conifer forest mortality and establishment before and after prescribed fire in Sequoia National Park, California. Forest Science 44: 341-355.

National Park Service. 2003. Grand Portage National Monument, final general management plan and environmental impact statement. Denver Service Center, Denver, Colorado, USA.

Nelson, M. E. 1995. Winter range arrival and departure of white-tailed deer in northeastern Minnesota. Canadian Journal of Zoology 73: 1069-1076. https://doi.org/10.1139/z95127

Oldham, M. J., W. D. Bakowski, and D. L. Sutherland. 1995. Floristic quality assessment system for southern Ontario. Natural Heritage Information Centre, Ontario Ministry of Natural Resources, Peterborough, Ontario, Canada.

Pastor, J., and R. J. Naiman. 1992. Selective foraging and ecosystem processes in boreal forests. The American Naturalist 139: 690-705. https://doi.org/10.1086/285353

R Core Team. 2012. R: A language and environment for statistical computing. R Foundation for Statistical Computing, Vienna, Austria.

Rooney, T. P., and D. A. Rogers. 2002. The modified floristic quality index. Natural Areas Journal 22: 340-344.

Rooney, T. P., and D. M. Waller. 2003. Direct and indirect effects of white-tailed deer in forest ecosystems. Forest Ecology and Management 181: 165-176. https://doi.org/10 .1016/S0378-1127(03)00130-0

Rouleau, I., M. Crête, G. Daigle, P. Etcheverry, and C. Beaudoin. 2002. Rapid estimation of plant biomass used as forage or cover by white-tailed deer, Odocoileus virginianus, and snowshoe hare, Lepus americanus, in mixed and coniferous forests of Southeastern Québec. Canadian FieldNaturalist 116: 523-528.

Sanders, S., and J. Grochowski. 2014. Alternative metrics for evaluating forest integrity and assessing change at four northern-tier U.S. National Parks. American Midland Naturalist 171: 185-203. https://doi.org/10.1674/0003-0031171.2.185

Sanders, S., and J. Kirschbaum. 2015. Forest health monitoring on the St. Croix National Scenic Riverway: shortterm change and longer-term projections. Journal of the Torrey Botanical Society 142: 271-282. https://doi.org/10 .3159/TORREY-D-14-00058.1
Schwilk, D. W., J. E. Keeley, E. E. Knapp, J. McIver, J. D. Bailey, C. J. Fettig, C. E. Fiedler, R. J. Harrod, J. J. Moghaddas, K. W. Outcalt, C. N. Skinner, S. L. Stephens, T. A. Waldrop, D. A. Yaussy, and A. Youngblood. 2009. The national fire and fire surrogate study: effects of fuel reduction methods on forest vegetation structure and fuels. Ecological Applications 19: 285-304. https:// doi.org/10.1890/07-1747.1

Smith, W. R. 2008. Trees and Shrubs of Minnesota. University of Minnesota Press, Minneapolis, Minnesota, USA.

Steinman, J. 2004. Forest health monitoring in the northeastern United States: disturbances and conditions during 1993-2002. NA-TP-01-04, USDA Forest Service, Northern Research Station, Newton Square, Pennsylvania, USA.

Stevens, D. L., Jr., and A. R. Olsen. 2004. Spatially balanced sampling of natural resources. Journal of the American Statistical Association 99: 262-278. https://doi.org/10.1198 /016214504000000250

Swink, F., and G. Wilhelm. 1994. Plants of the Chicago Region, Fourth Edition. The Indiana Academy of Science, Indianapolis, Indiana, USA.

Tanentzap, A. J., D. R. Bazely, S. Koh, M. Timciska, E. G. Haggith, T. J. Carleton, and D. A. Coomes. 2011. Seeing the forest for the deer: do reductions in deer-disturbance lead to forest recovery? Biological Conservation 144: 376-382. https://doi.org/10.1016/j.biocon.2010.09.015

Taverna, K., R. K. Peet, and L. C. Phillips. 2005. Long-term change in ground-layer vegetation of deciduous forests of the North Carolina piedmont, USA. Journal of Ecology 93: 202-213. https://doi.org/10.1111/j.0022-0477.2004.009 $65 . \mathrm{x}$

Wan, X., S. M. Landhäusser, V. J. Lieffers, and J. J. Zwiazek. 2006. Signals controlling root suckering and adventitious shoot formation in aspen (Populus tremuloides). Tree Physiology 26: 681-687. https://doi.org/10 $.1093 /$ treephys/26.5.681

Webster, C. R., M. A. Jenkins, and G. R. Parker. 2001. A field test of herbaceous plant indicators of deer browsing intensity in mesic hardwood forests of Indiana, USA. Natural Areas Journal 21: 149-158.

White, M. A. 2012. Long-term effects of deer browsing: composition, structure and productivity in a northeastern Minnesota old-growth forest. Forest Ecology and Management 269: 222-228. https://doi.org/10.1016/j.foreco.2011 .12 .043

White, M., and G. E. Host. 2003. Historic disturbance regimes and natural variability of Grand Portage National Monument Forest Ecosystems. Report to Grand Portage National Monument, Grand Portage, Minnesota, USA.

Wilhelm, G. S., and L. A. Masters. 1995. Floristic Quality Assessment in the Chicago Region and Application Computer Programs, Revised. The Morton Arboretum, Lisle, Illinois. USA.

Wolff, J. O. 1978. Food habits of snowshoe hares in interior Alaska. Journal of Wildlife Management 42: 148-153. https ://doi.org/10.2307/3800702

York, R. A., J. J. Battles, R. C. Wenk, and D. Saah. 2012. A gap-based approach for regenerating pine species and reducing surface fuels in multi-aged mixed conifer stands in the Sierra Nevada, California. Forestry 85: 203-213. https:// doi.org/10.1093/forestry/cpr058

Received 27 October 2015

Accepted 24 May 2017 